Vol 12, Issue 2, 2019

\title{
PHYTOCHEMICAL ANALYSIS, HIGH-PERFORMANCE LIQUID CHROMATOGRAPHY, AND EX VIVO ANTIOXIDANT POTENTIAL OF A HERBAL FRUIT EXTRACT
}

\author{
GEETIKA SHARMA, VIPASHA SHARMA, TULIKA MISHRA* \\ Department of Biotechnology, University Institute of Biotechnology, Chandigarh University, Gharuan, Mohali, Punjab, India. \\ Email: geetikabiotech.cgc@gmail.com
}

Received: 15 September 2018, Revised and Accepted: 23 October 2018

\section{ABSTRACT}

Objective: The objective of the present investigation was to determine the presence of various phytochemicals in an ethanolic herbal fruit extract (HFE) made up by a blend of fruits of Phyllanthus emblica (PE), Ananas comosus (AC), Punica granatum (PG), and Terminalia chebula (TC). Followed by a qualitative high-performance liquid chromatography (HPLC) analysis for standardization of the extract using ascorbic acid and gallic acid as standards, this study was also aimed at the determination of ex vivo antioxidant potential and calculation of inhibitory concentration (IC $\mathrm{C}_{50}$ ) value of HFE.

Methods: The analysis of phytochemicals present in HFE was done qualitatively by methods as described by various researchers. Reversed-phase HPLC was carried out on a C-18 column on gradient mode, using methanol and acetic acid as mobile phase. Ex vivo antioxidant potential was evaluated by inhibition of lipid peroxidation (LPO) method by the preparation of packed cell volume.

Results: The results revealed the presence of multiple phytoconstituents in the HFE, and through the chromatographic analysis, the presence of gallic and ascorbic acid as marker compounds was achieved. IC50 values calculated after LPO inhibition method was found to be $21.87 \mu \mathrm{g} / \mathrm{ml}$ and $25.63 \mu \mathrm{g} / \mathrm{ml}$ for ascorbic acid (as standard) and ethanolic HFE, respectively.

Conclusion: The use of herbal antioxidants can provide protection to the human body by fighting against multiple diseases caused as a result of the accumulation of free radicals, generated in the normal metabolic processes going on inside the body. Nowadays, researchers are amused to see the long-term positive effects of using a combination of antioxidants, for example, a polyherbal formulation, rather than single entities.

Keywords: Antioxidants, Herbal fruit extract, High-performance liquid chromatography, Phytochemicals, Ex vivo assay.

(C) 2019 The Authors. Published by Innovare Academic Sciences Pvt Ltd. This is an open access article under the CC BY license (http://creativecommons. org/licenses/by/4. 0/) DOI: http://dx.doi.org/10.22159/ajpcr.2019.v12i2.29760

\section{INTRODUCTION}

Nature has provided many things for humankind over the years, including the tools for the first attempts at therapeutic intervention. The use of plants dates back to almost all the civilization. Even primates have been known to chew certain leaves when suffering from gastrointestinal disturbances [1]. There is an ever-growing interest in investigating different species of plants to identify their potential therapeutic applications due to a tremendous historical legacy in folkloric use of plants as medicine and their easy availability, costeffectiveness, presumed safety, and biological friendliness than totally synthetic molecules [2].

With the advancement in technology and move toward a progressive life, humankind is heading toward many diseases such as cancer, AIDS, tuberculosis, diabetes, chronic inflammatory diseases, atherosclerosis, and neurodegenerative diseases that all are invariably associated with immune system [3]. One of the major causes of many of these diseases is oxidative stress caused by disturbance in the balance between antioxidants and prooxidants.

Plants cope up with oxidative stress by developing an array of defense strategies (antioxidant system). Both enzymatic and non-enzymatic systems are included under the antioxidative system. Plants have natural antioxidants in almost all their parts. Sato et al. [4] and Meyer et al. [5] studied the antioxidative characteristics of phenolic compounds from grapes including scavenging of free radicals, inhibition of lipid oxidation, reduction of hydroperoxide formation, and so on. Phytochemicals found in plants and their products are bioactive compounds that are non-nutritious in nature and usually found in vegetables, fruits, cereal grains, and plant-based foods. Consumption of phytochemicals is linked with a decline in risk of several types of chronic diseases due to their antioxidant potential and free radical scavenging effects [6].

This study is aimed at the determination of bioactive compounds and ex vivo antioxidant potential of a mixture made using the fruits of four different plants mixed in a specified concentration. The herbal fruit extract (HFE) mixture contains the fruits of Phyllanthus emblica (PE), Ananas comosus (AC), Punica granatum (PG), and Terminalia chebula (TC).

\section{METHODS}

Plant material and authentication

The plant material used for the preparation of HFE includes the fruits of PE, AC, PG, and TC with accession number 21126, 21127, 21128, and 21129, respectively, assigned by a Taxonomist at Panjab University, Chandigarh.

\section{Preparation of HFE}

The individual extracts of all the plant materials used in the present study were prepared in ethanol as a solvent by a method described earlier in a previous study [7]. The ethanolic combination of fruits and herbs was selected for this study as it possessed the highest in vitro antioxidant potential that was previously determined by hydroxyl and 2,2-diphenyl-1-picrylhydrazyl radical scavenging assay. Therefore, the ethanolic extract of herbs and fruits combined in a specific concentration as revealed in the earlier studies $(\mathrm{PE}=175 \mu \mathrm{g} / \mathrm{ml}, \mathrm{AC}=125 \mathrm{ug} / \mathrm{ml}$, $\mathrm{PG}=261.361 \mathrm{ug} / \mathrm{ml}$, and $\mathrm{TC}=400 \mathrm{ug} / \mathrm{ml}$ ) [7] was used for further analysis of bioactive constituents and evaluation of ex vivo antioxidant potential through inhibition of lipid peroxidation (LPO) method. 


\section{Phytochemical screening}

Phytochemical analysis is useful to evaluate the chemical constituents present in the crude drug and help in the estimation of specific constituents soluble in a particular solvent. The plants, thus, find their medicinal values due to the presence of respective phytochemical constituents [8]. Screening of the phytochemicals is an important tool in the analysis of bioactive compounds. Moreover, it is a convenient, fast, and inexpensive assay that allows researchers to know about the presence of various phytochemicals in a mixture. Phytochemical analysis was carried out for both, that is, individual fruits and herbs and in mixture (HFE). The ethanolic extracts of TC, PE, AC, PG, and HFE were subjected to the qualitative detection of various phytochemicals as per the methodology discussed in Table 1.

Chemicals and standard for high-performance liquid chromatography (HPLC)

Acetic acid and methanol of HPLC grade were procured from HiMedia Laboratories Ltd., Mumbai, India, whereas ascorbic acid and gallic acid used as standards were purchased from Sigma-Aldrich (USA). Standard sock solutions of $100 \mu \mathrm{g} / \mathrm{ml}$ were prepared in methanol. The HFE was filtered through $0.45 \mu \mathrm{m}$ millipore filter before being injected into the column.

\section{HPLC analysis of HFE}

The chromatographic equipment of Shimadzu HPLC system comprising LC - 10ATVP pump, diode array detector (SPD-M10AVP), and Supelco C18 (RP) column $(25 \mathrm{~cm} \times 4.6 \mathrm{~mm} ; 5 \mu \mathrm{m})$ controlled at $30^{\circ} \mathrm{C}$ was employed for the chromatographic analysis of HFE. Data acquisition and peak integration were performed using Shimadzu Class VP Series software and results were obtained by comparison with standards at $278 \mathrm{~nm}$ UV detection. The gradient system of mobile phase used for the study comprised acetic acid $(0.1 \% \mathrm{v} / \mathrm{v})$ and methanol A gradient was used as 0-15 $\mathrm{min}, 5 \%$ methanol; $15-40 \mathrm{~min}, 80 \%$ methanol; 40 $42 \mathrm{~min}, 5 \%$ methanol; and $42-50 \mathrm{~min}, 5 \%$ methanol. The flow rate of $1.0 \mathrm{ml} / \mathrm{min}$ and injection volume of $20 \mu \mathrm{l}$ were employed. The chromatographic conditions described by Sawant et al. were followed with slight modifications, and the use of ascorbic acid and gallic acid was done as marker compounds to be analyzed in HFE [14].

\section{Evaluation of ex vivo antioxidant potential of HFE}

The ex vivo antioxidant potential of HFE was evaluated by inhibition of LPO method in packed cell volume (PCV). For the preparation of PCV, the collection of human blood in Alsever's solution in the ratio of 2:1 was done, followed by centrifugation at $1000 \times \mathrm{g}$ at $4^{\circ} \mathrm{C}$ for $10 \mathrm{~min}$. The pallet was collected and washed thrice with PBS (pH 7.4). Determination of LPO inhibition was done after adjusting the PCV to 5\% [15].

\section{Determination of percentage inhibition of LPO in PCV}

Ex vivo antioxidant potential was evaluated by inhibition of LPO by slight modifications in the method described by Stocks and Dormandy [16]. To $2 \mathrm{ml}$ of 5\% PCV added $1 \mathrm{ml}$ of hydrogen peroxide, $0.1 \mathrm{ml}$ of sodium azide, and $0.1 \mathrm{ml}$ of different concentrations of HFE dissolved in PBS, the volume was made to $4 \mathrm{ml}$ with PBS and incubated at $37^{\circ} \mathrm{C}$ for $60 \mathrm{~min}$. Reaction was stopped by adding $2 \mathrm{ml}$ of ice-chilled TCA. The mixture was shaken vigorously and centrifuged at $\times 200 \mathrm{~g}$ for 15 min. Supernatant was transferred to screw-capped vials, followed by addition of $1 \mathrm{ml}$ of tetrabutylammonium (TBA). The vials were kept in boiling water bath for $30 \mathrm{~min}$ and cooled. Intensity of pink color developed was read at $532 \mathrm{~nm}$ against TBA as blank. The percentage inhibition of LPO was determined as follows:

Inhibition of lipid peroxidation $(\%)=\left(\mathrm{A}_{\text {control }}-\mathrm{A}_{\text {sample }}\right) / \mathrm{A}_{\text {control }} \times 100$

\section{RESULTS AND DISCUSSION}

\section{Phytochemical analysis}

The naturally occurring substances called phytochemicals have proved to be immensely beneficial for human health as it offers a significant amount of antioxidant as well as anti-inflammatory potential. Phytochemical screening of ethanolic fruit extract of TC, PE, AC, PG, and HFE revealed the presence of various bioactive compounds as shown in Table 2. The qualitative phytochemical analysis carried out in ethanolic extract of PE, AC, PG, TC, and HFE revealed the presence of 7, $6,7,5$, and 8 bioactive compounds, respectively. A similar investigation was carried out to study the phytochemical composition and cytotoxic activity of pineapple extract, and it revealed the presence of flavonoids, phenols, coumarins, steroids, terpenoids, and quinones. The pineapple extract also exhibited a significant cytotoxic activity against oral cancer cell lines as revealed by the MTT assay carried out using different concentrations of the extract [17].

In the present investigation, it was observed that ethanolic HFE showed the maximum expression of phytochemicals out of all other samples revealing the presence of alkaloids, flavonoids, saponins, steroids, quinones, phenolic compounds, tannins, and terpenoids, whereas lacking glycosides and anthraquinones. Similar type of study was carried

Table 1: The details of qualitative phytochemical analysis along with methodology and expected results as per standard methods followed

\begin{tabular}{|c|c|c|c|}
\hline Phytochemical & Test performed & Methodology and expected observation & References \\
\hline Alkaloids & Wagner test & $\begin{array}{l}\text { Added } 2 \mathrm{ml} \text { of sample in a test tube and few drops of } 1 \% \mathrm{HCl} \text {, followed by } \\
\text { addition of } 1 \mathrm{ml} \text { of Wagner's reagent. Appearance of reddish-brown color } \\
\text { will indicate positive test }\end{array}$ & [9] \\
\hline Flavonoids & $\mathrm{NaOH}$ test & $\begin{array}{l}\text { To } 1 \mathrm{ml} \text { of sample added few drops of } 2 \mathrm{~N} \mathrm{NaOH} \text { solution. Occurrence of } \\
\text { yellow color will indicate a positive result }\end{array}$ & [10] \\
\hline Saponins & Foam test & $\begin{array}{l}\text { Took } 1 \mathrm{ml} \text { of sample and added few drops of water, followed by vigorous } \\
\text { shaking. Observed for the presence and persistence of froth for few minutes }\end{array}$ & {$[10]$} \\
\hline Steroids & Liebermann-Burckhardt test & $\begin{array}{l}\text { To } 1 \mathrm{ml} \text { of sample added } 1 \mathrm{ml} \text { of chloroform, } 2-3 \mathrm{ml} \text { of acetic anhydride } \\
\text { followed by } 1-2 \text { drops of conc. } \mathrm{H}_{2} \mathrm{SO}_{4} \text {. Dark green color will be a positive result }\end{array}$ & {$[11]$} \\
\hline Quinones & $\mathrm{H}_{2} \mathrm{SO}_{4}$ & $\begin{array}{l}\text { To } 1 \mathrm{ml} \text { of sample added } 1 \mathrm{ml} \text { of conc. } \mathrm{H}_{2} \mathrm{SO}_{4} \text {. Presence of red color will } \\
\text { indicate a positive test }\end{array}$ & {$[10]$} \\
\hline Phenolic Compounds & $\mathrm{FeCl}_{3}$ test & $\begin{array}{l}\text { In } 1 \mathrm{ml} \text { of sample, added } 2 \mathrm{ml} \text { distilled water followed by } 3-4 \text { drops of ferric } \\
\text { chloride solution. Formation of blue-green color will give a positive result }\end{array}$ & {$[10]$} \\
\hline Tannins & Braemer's test & $\begin{array}{l}\text { Added } 2 \mathrm{ml} \text { of } 10 \% \text { alcoholic ferric chloride to } 2 \mathrm{ml} \text { of sample. Dark blue } \\
\text { color will indicate its presence }\end{array}$ & {$[11]$} \\
\hline Glycosides & Keller-Kiliani test & $\begin{array}{l}\text { In } 1 \mathrm{ml} \text { of sample, added } 3 \mathrm{ml} \text { of chloroform and } \mathrm{H}_{2} \mathrm{SO}_{4} \text { to form a layer. } \\
\text { Brown ring at interphase indicates positive result }\end{array}$ & {$[12]$} \\
\hline Terpenoids & Salkowski test & $\begin{array}{l}2 \mathrm{ml} \text { of chloroform was added to } 1 \mathrm{ml} \text { of sample followed by } 3 \mathrm{ml} \text { of conc. } \\
\mathrm{H}_{2} \mathrm{SO}_{4} \text {. Red-brown color at upper phase will indicate a positive result }\end{array}$ & [13] \\
\hline Anthraquinones & Borntrager's test & $\begin{array}{l}\text { Added } 2 \mathrm{ml} \text { of chloroform to } 2 \mathrm{ml} \text { of sample followed by addition of } 1 \mathrm{ml} \text { of } \\
10 \% \text { ammonia solution. Pink-red color in lower layer indicates a positive result }\end{array}$ & {$[12]$} \\
\hline
\end{tabular}




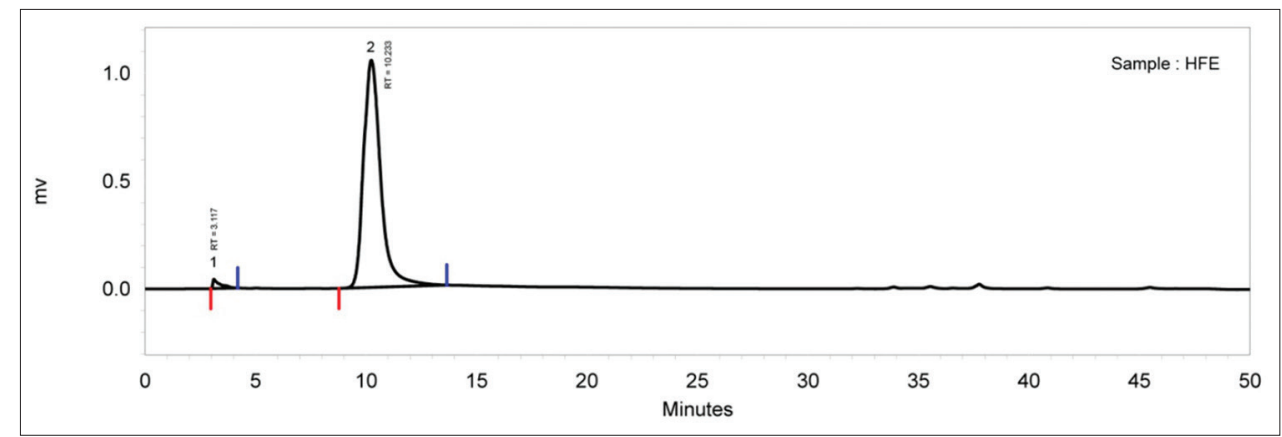

Fig. 1: The chromatogram of herbal fruit extract with two peaks labeled as 1 and 2 with retention time values of 3.117 and 10.233 min, respectively

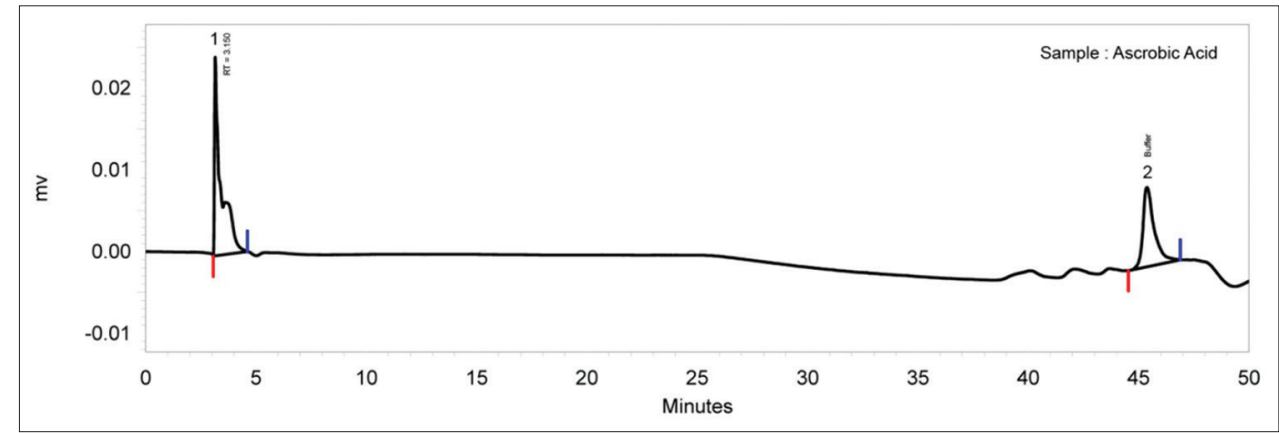

Fig. 2: The chromatogram of ascorbic acid with two peaks labeled as 1 and 2 with retention time values of 3.150 and 45.375 min (buffer), respectively

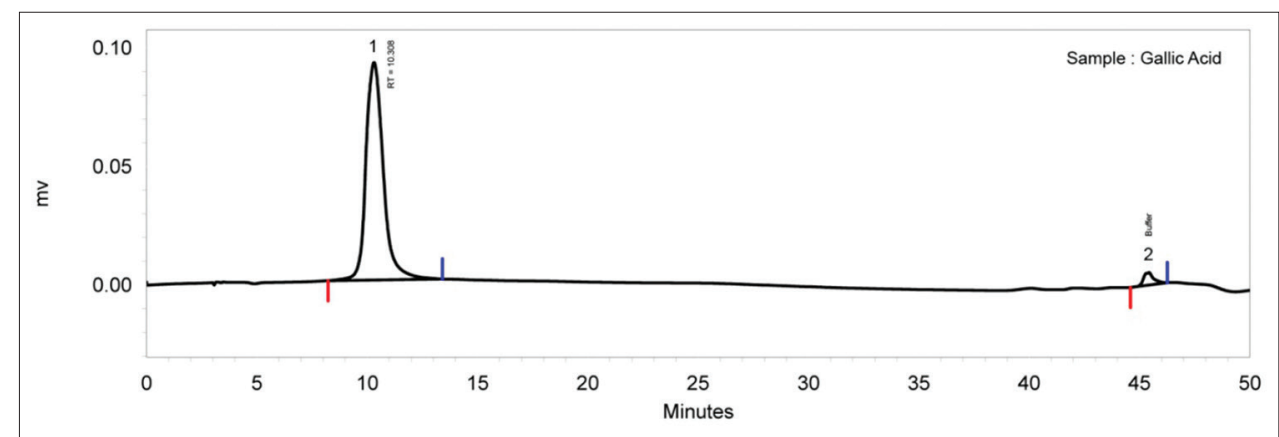

Fig. 3: The chromatogram of gallic acid with two peaks labeled as 1 and 2 with retention time values of 10.308 and 45.433 min (buffer), respectively

Table 2: The results of qualitative phytochemical screening of ethanolic extracts of PE, AC, PG, TC, and HFE

\begin{tabular}{llllll}
\hline Phytochemical & PE & AC & PG & TC & HFE \\
\hline Alkaloids & + & + & + & + & + \\
Flavonoids & + & + & - & + & + \\
Saponins & - & + & + & - & + \\
Steroids & - & + & + & - & + \\
Quinones & + & + & - & - & + \\
Phenolic compounds & + & - & + & + & + \\
Tannins & + & - & + & + & + \\
Glycosides & - & - & - & + & - \\
Terpenoids & + & + & + & - & + \\
Anthraquinones & + & - & + & - & - \\
\hline
\end{tabular}

PE: Phyllanthus emblica, AC: Ananas comosus, PG: Punica granatum,

TC: Terminalia chebula, HFE: Herbal fruit extract. Symbol $(+)$ indicates the presence and (-) indicates the absence of a phytoconstituents in the respective ethanolic sample

out on a fruit drink made up by a blend of equal portions of cucumber $(50 \%)$ and pineapple (50\%) juices mixed with clove and ginger powder spices at a conc. of $0.25 \%, 0.5 \%, 0.75 \%$, and $1 \%(\mathrm{w} / \mathrm{v})$, respectively. The phytochemical compounds identified in this formulated drink include alkaloids, flavonoids, saponins, steroids, tannins, terpenoids, and phlobatannins [18].

\section{HPLC analysis of HFE}

The ethanolic HFE was standardized and investigated for the qualitative analysis of ascorbic and gallic acid as marker compounds. For HPLC analysis, the mobile phase consisting of gradient elution of methanol and $0.1 \%(\mathrm{v} / \mathrm{v})$ acetic acid in HPLC-grade water with Supelco C18 reverse-phase column at a flow rate of $1.0 \mathrm{ml} / \mathrm{min}$ was used. Under this system, the chromatogram of ascorbic acid, gallic acid, and HFE was obtained as shown in Figs. 1-3, respectively (as shown in Table 4 and 5). The retention time (RT) for ascorbic and gallic acid was $3.15 \mathrm{~min}$ and $10.308 \mathrm{~min}$, respectively (Tables 4 and 5). A study states a reversed-phase high-performance liquid chromatography method developed and validated for simultaneous estimation of ascorbic and gallic acid in PE. The ascorbic and gallic acid was eluted with RT of 3.60 and $10.77 \mathrm{~min}$, respectively [14]. The present study revealed the emergence of two peaks in the chromatogram of HFE with RT values of 3.117 and $10.233 \mathrm{~min}$ (Table 3) that approximately coincides with 
Table 3: The results of chromatographic analysis of HFE representing RT values, area, and percent area

\begin{tabular}{llll}
\hline Peak No. (HFE) & RT (min) & Area $(\mathbf{m v})$ & Area (\%) \\
\hline 1 & 3.117 & 975445 & 1.68 \\
2 & 10.233 & 57042865 & 98.32 \\
Total & & 58018310 & 100 \\
\hline
\end{tabular}

RT: Retention time, HFE: Herbal fruit extract

Table 4: The results of chromatographic analysis of ascorbic acid representing $\mathrm{RT}$ values, area, and percent area

\begin{tabular}{llll}
\hline Peak no. (ascorbic acid) & RT (min) & Area (mv) & Area (\%) \\
\hline 1 & 3.150 & 491695 & 58.64 \\
2 & 45.375 & 346775 & 41.36 \\
Total & & 838470 & 100.00 \\
\hline
\end{tabular}

RT: Retention time

Table 5: The results of chromatographic analysis of gallic acid representing $\mathrm{RT}$ values, area, and percent area

\begin{tabular}{llll}
\hline Peak No. (gallic acid) & RT (min) & Area (mv) & Area (\%) \\
\hline 1 & 10.308 & 5036746 & 96.82 \\
2 & 45.433 & 165165 & 3.18 \\
Total & & 5201911 & 100.00 \\
\hline
\end{tabular}

RT: Retention time

Table 6: Different concentrations of HFE analyzed for percentage inhibition of lipid peroxidation in an ex vivo system and calculated IC50 values are also represented. Values are mean of three replicates \pm SD

\begin{tabular}{llll}
\hline HFE & & \multicolumn{2}{c}{ \% inhibition of LPO } \\
\cline { 1 - 1 } Conc. $(\boldsymbol{\mu g} / \mathbf{m l})$ & & Ascorbic acid $(\%)$ & Ethanolic HFE (\%) \\
\hline 0 & 0 & 0 \\
10 & $39.64 \pm 1.96$ & $34.99 \pm 1.90$ \\
20 & $57.88 \pm 1.57$ & $49.87 \pm 1.57$ \\
30 & $69.4 \pm 1.58$ & $59.04 \pm 2.13$ \\
40 & $77.66 \pm 2.23$ & $70.95 \pm 0.71$ \\
50 & $84.93 \pm 1.25$ & $79.57 \pm 0.72$ \\
IC50 $(\mu \mathrm{g} / \mathrm{ml})$ & 21.87 & 25.63 \\
\hline
\end{tabular}

SD: Standard deviation, IC50: Inhibitory concentration, LPO: Lipid peroxidation, HFE: Herbal fruit extract

that of standard values obtained from the standard chromatograms of ascorbic and gallic acid. Thus, it highlights the presence of these two bioactive compounds in the HFE and their presence can further be a basis for this herbal fruit mixture to possess a significant antioxidant and even anticancer potential. In a study, the HPLC method with gradient elution was developed for the quantification of ascorbic acid, free phenolic acids such as gallic acid and methyl gallate, and flavonoids in four different solvent extracts of wild edible leaves of Zanthoxylum acanthopodium collected from Meghalaya state of India. The results revealed a high concentration of ascorbic acid $(16.8 \mathrm{mg} / \mathrm{g}$ of dry plant material) and gallic acid $(0.952 \mathrm{mg} / \mathrm{g}$ of dry plant material $)$ in $1 \%$ aq. acetic acid extract as compared to the $80 \%$ aq. ethanol extract of the plant [19].

\section{Ex vivo evaluation of percent inhibition of LPO}

The scavenging of free radicals can be attained by natural and synthetic antioxidant, but antioxidants from natural origin have attracted special interest for the reason that they guard the human body from free radicals without any side effect [18]. In this study, the HFE was further subjected to ex vivo evaluation of antioxidant potential and was compared with known antioxidant, that is, L-ascorbic acid. The results demonstrated that the bioactivity of HFE and ascorbic acid was

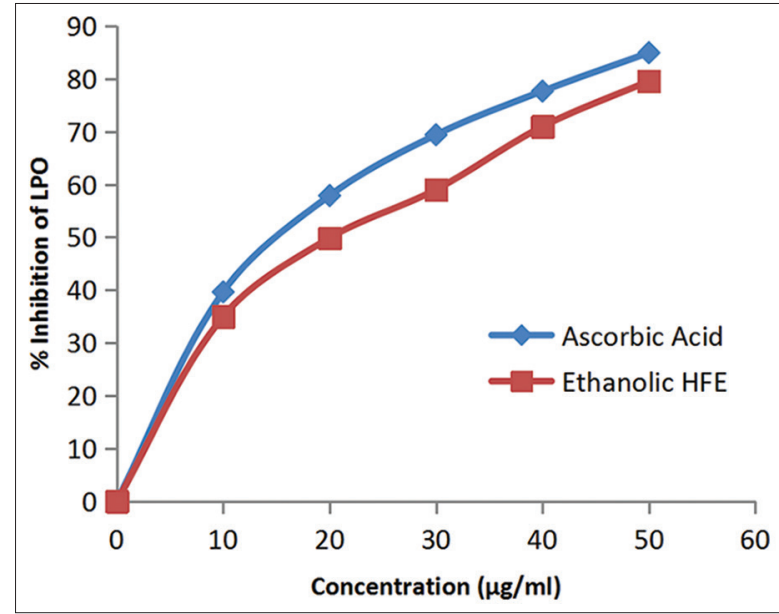

Fig. 4: Comparison of sample (herbal fruit extract [HFE]) and ascorbic acid as standard through ex vivo evaluation of percent inhibition of lipid peroxidation in packed cell volume (PCV). The inhibitory concentration value of HFE is calculated to be $25.63 \mu \mathrm{g} / \mathrm{ml}$ with the help of linear regression equation being $y=1.471 x+12.29$ and the value of $R^{2}=0.920$

concentration dependent as shown in Fig. 4 and Table 6. The inhibitory concentration (IC50) value of both, the standard and the sample, was different. The HFE showed the IC50 value at $21.87 \mu \mathrm{g} / \mathrm{ml}$ and ascorbic acid showed at $25.63 \mu \mathrm{g} / \mathrm{ml}$. Similar kind of study was carried out to evaluate the antioxygenic potential of a tissue culture raised Mentha spicata (SPR 8) using an ex vivo model involving human erythrocytes. Herein, the results of LPO inhibition revealed a significantly lower degree of LPO in test erythrocytes as compared to control, indicating increased protection of erythrocytes against $\mathrm{H}_{2} \mathrm{O}_{2}$, effect being better at higher concentration of plant extract [15].

\section{CONCLUSION}

The use of multiple antioxidants can actually enhance the protective role of defense mechanisms of our body and hence offer protection against harmful effects of the accumulation of free radicals. It has been seen that in the past two decades, there has been a widespread interest in the plant-based chemical composition of medicine. Substantial evidence indicates that antioxidants from multiple herbs and other plant products are of major importance in disease prevention. By preventing or postponing the onset of degenerative diseases, antioxidants may be of immense importance in enhancing the eminence of life.

\section{ACKNOWLEDGMENT}

The authors would like to offer deepest respect and profound appreciation to senior authorities of Chandigarh University and CIL, NIPER (Mohali), for providing necessary facilities to carry out the research work.

\section{AUTHORS' CONTRIBUTION}

All the authors have equally contributed.

\section{CONFLICTS OF INTEREST}

The authors declared that they have no conflicts of interest.

\section{REFERENCES}

1. Cragg GM, Newman DJ, Weiss RB. Coral reefs, forests, and thermal vents: The worldwide exploration of nature for novel antitumor agents. Semin Oncol 1997;24:156-63.

2. Balunas MJ, Kinghorn AD. Drug discovery from medicinal plants. Life Sci 2005;78:431-41.

3. Kidd P. Th1/Th2 balance: The hypothesis, its limitations, and implications for health and disease. Altern Med Rev 2003;8:223-46.

4. Sato M, Ramarathnam N, Suzuki Y, Ohkubo T, Takeuchi M, Ochi H. 
Varietal differences in the phenolic content and superoxide radical scavenging potential of wines from different sources. J Agric Food Chem 1996;44:37-41.

5. Meyer AS, Yi OS, Pearson DA, Waterhouse AL, Frankel EN. Inhibition of human low density lipoprotein oxidation in relation to composition of phenolic antioxidants in grapes (Vitis vinifera). J Agric Food Chem 1997:45:1638-43.

6. Zhang YJ, Gan RY, Li S, Zhou Y, Li AN, Xu DP, et al. Antioxidant phytochemicals for the prevention and treatment of chronic diseases. Molecules 2015;20:21138-56.

7. Sharma G, Sharma V, Mishra T. Enhancement of in vitro antioxidant potential of Terminalia chebula by various fruit extracts and optimization of concentration by response surface methodology. Asian J Pharm Clin Res 2018;11:228-33.

8. Duraiswamy B, Singanan M, Varadarajan V. Physicochemical, phytochemicals and antioxidant evaluation of Guazuma ulmifolia fruit. Int J Pharm Pharm Sci 2018;10:87-91.

9. Chanda SV, Parekh J, Karathia N. Evaluation of antibacterial activity and phytochemical analysis of Bauhinia variegate. L bark. Afr J Biomed Res 2006;9:53-6.

10. Trease GE, Evans WC. Pharmacognosy: A Physicians Guide to Herbal Medicine. $13^{\text {th }}$ ed. London, UK: Bailliere Tindall; 1989

11. Kumar GS, Jayaveera KN, Kumar CK, Sanjay UP, Swamy BM, Kumar DV. Antimicrobial effects of Indian medicinal plants against acne-inducing bacteria. Trop J Pharm Res 2007;6:717-23.

12. Onwukaeme DN, Ikuegbvweha TB, Asonye CC. Evaluation of phytochemical constituents, antibacterial activities and effect of exudates of Pycanthus angolensis Weld Warb (Myristicaceae) on corneal ulcers in rabbits. Trop J Pharm Res 2007;6:725-30.

13. Edeoga HO, Okwu DE, Mbaebie BO. Phytochemical constituents of some Nigerian medicinal plants. Afr J Biotechnol 2005;4:685-8.

14. Sawant L, Prabhakar B, Pandita N. Quantitative HPLC analysis of ascorbic acid and gallic acid in Phyllanthus emblica. J Anal Bioanal Tech 2010;1:1-4.

15. Deep A, Rana P, Gosal SS, Soni G. Antioxidant potential of tissue cultured Mentha spicata. BioMedRx 2013;1:90-6.

16. Stocks J, Dormandy TL. The autoxidation of human red cell lipids induced by hydrogen peroxide. Br J Haematol 1971;20:95-111.

17. Menon A, Priya V, Gayathri R. Preliminary phytochemical analysis and cytotoxicity potential of pineapple extract on oral cancer cell lines. Asian J Pharm Clin Res 2016;9:140-3.

18. Babajide JM, Olaluwoye AA, Taofik ST, Adebisi MA. Physicochemical properties and phytochemical components of spiced cucumberpineapple fruit drink. Niger Food J 2013;31:40-52.

19. Seal T. HPLC Determination of phenolic acids, flavonoids and ascorbic acid in four different solvent extracts of Zanthoxylum acanthopodium, a wild edible plant of Meghalaya state of India. Int J Pharm Pharm Sci 2016;8:103-9. 